\title{
Anatomo-radiographic description of the axial skeleton of the crab-eating fox (Cerdocyon thous) ${ }^{1}$
}

\author{
Janaína D. Barisson², Cristiane H. Louro², Sheila J.T. Dias², Flávio S. Jojima³, \\ Murilo S. Ferreira ${ }^{2}$ and Fabrício S. Oliveira ${ }^{2 *}$
}

\begin{abstract}
Barisson J.D., Louro C.H., Dias S.J.T., Jojima F.S., Ferreira M.S. \& Oliveira F.S. 2012. Anatomo-radiographic description of the axial skeleton of the crab-eating fox (Cerdocyon thous). Pesquisa Veterinária Brasileira 32(Supl.1):1-3. Departamento de Medicina Veterinária, Universidade Estadual de Maringá, Campus Umuarama, Cx. Postal 65, Umuarama, PR 87501-970, Brazil. E-mail: singaretti@ig.com.br

The aim of this study was to describe the axial skeleton of a wild Brazilian carnivorous, the crab-eating fox (Cerdocyon thous). Five specimens of crab-eating fox were previously unfrozen for radiographic exams and their bones went through dissection and chemical maceration. This animal presents seven cervical vertebrae, and from the third on, they become shorter and wider than the other ones e the spinous process was makeable from the fifth cervical vertebrae on. There are thirteen thoracic vertebrae and the spinous process of the lumbar vertebrae, which are seven, decreases from the fifth on. The sacrum is formed by two vertebrae and there are twenty or twenty one caudal vertebrae. It can be concluded that the crab-eating fox axial skeleton is similar to that of the domestic dog.
\end{abstract}

INDEX TERMS: Anatomy, radiography, skeleton, Cerdocyon thous, crab-eating fox.

RESUMO.- [Descrição anátomo-radiográfica do esqueleto axial do cachorro-do-mato (Cerdocyon thous).] 0 objetivo deste trabalho foi descrever o esqueleto axial de um carnívoro selvagem brasileiro, o cachorro-do-mato (Cerdocyon thous). Cinco animais foram previamente descongelados para exames radiográficos e posteriormente submetidos a dissecação óssea e maceração química. Os animais apresentavam sete vértebras cervicais e, à partir da terceira, eram mais curtas e largas e o processo espinhoso mais evidente a partir da quinta vértebra cervical. Há treze vértebras torácicas e o processo espinhoso das vértebras lombares, que são sete, diminui partir da quinta vértebra. 0 sacro é constituído por duas vértebras fundidas e há 20 ou 21 vértebras caudais. Pode-se concluir que o esqueleto axial do cachorro-do-mato se assemelha ao do cão doméstico.

TERMOS DE INDEXAÇÃO: Anatomia, radiografia, esqueleto axial, Cerdocyon thous, cachorro-do-mato.

\footnotetext{
${ }^{1}$ Received on April 3, 2012.

Accepted for publication on August 10, 2012.

${ }^{2}$ Departamento de Veterinária, Universidade Estadual de Maringá (UEM), Campus Umuarama, Caixa Postal 65, Umuarama, PR 87501-970, Brazil. *Corresponding author: singaretti@ig.com.br

${ }^{3}$ Departamento de Medicina Veterinária, Campus de Palotina, Universidade Federal do Paraná (UFPR), Rua Pioneiro 2153, Palotina, PR 85950000, Brazil.
}

\section{INTRODUCTION}

The axial skeleton includes the skull, the spine, the ribs and the sternum (König \& Liebich 2002). In wild species, there are few anatomical or radiographic information on their skeleton, particularly in relation to wild carnivores, such as the crab-eating fox (Cerdocyon thous), which makes it difficult to describe diseases and interpret lab tests involving such bones. In rodents, there are anatomical-radiographic descriptions for the axial and appendicular skeleton of the paca (Agouti paca) (Oliveira et al. 2007a,b) and the agoutis (Dasyprocta azarae) (Oliveira et al. 2009a,b).

The crab-eating fox is a species belonging to the Canidae family, occurring in almost all of Brazil, except in some of the Amazon regions. This species is found both in forest and field areas and it has preferentially nocturnal habits, moving alone or in pairs, throughout trails, forest edges and roads in search of food (Rocha et al. 2004).

This paper aims to give an anatomical and radiographic description for the axial skeleton of a Brazilian wild carnivorous, that is, the crab-eating fox, in order to compare the data obtained with the one found out in the literature data on other species.

\section{MATERIALS AND METHODS}

We used six animals that were found dead onto roads and which were donated for further studies by the Environmental Police for 
the Animal Anatomy Laboratory of the Veterinary Medicine course taking place at the State University of Maringá located in the city of Umuarama, state of Paraná. The animals remained frozen at $-18^{\circ} \mathrm{C}$ until they were thawed in $10^{\circ} \mathrm{C}$ cold for 48 hours before the radiographic examination. The samples showed no change in their external morphology and were radiographed in lateral right, dorsal and ventral position to get their skeletons described.

After the dissection, each skeleton was subjected to the controlled chemical maceration process (Rodrigues 1998), and then it was placed for drying at room temperature for one week and, thereafter, it was analyzed and described. The terminology used for the description is according to the Illustrated Veterinary Anatomical Nomenclature (Schaller 1999).

\section{RESULTS}

The skull of the grab-eating fox (Cerdocyon thous) is slightly elongated in the caudal part, it also has a larger width at the zygomatic process of temporal bone. The orbits are incomplete and located in the middle third between the occipital and nasal bones, laterally.

This wild Brazilian carnivorous has seven cervical vertebrae, thirteen thoracic, seven lumbar, two fused sacral and twenty-one caudal ones (Fig.1). The bodies of the cervical vertebrae decrease gradually towards the cranial-caudal part, and they are dorsoventrally compressed. The first cervical, that is, the atlas, has wide lateral wings, which are also flat, well-developed and with the alar notch present in cranial border. It presents the dorsal and ventral portion respectively without projection and a slightly developed ventral tubercle. The axis has well-developed odontoid and spinous processes and a slightly wider transversal process in-between the distances of the two joint caudal surfaces. The other five cervical vertebrae are shorter and wider and the spinous process is evident from the fifth cervical vertebra on.

Regarding the chest regions, the more caudal the vertebra presents itself, the larger the vertebral body is. The first three spinous processes are virtually perpendicular and they have the same length, becoming gradually more oblique and less developed until the tenth vertebra, but remaining equal in the last three ones.

The lumbar vertebrae have well-developed transverse processes, which are cranially and ventrally directed. The spinous processes are broad in its ventral portion and they narrow down in its dorsal portion. Moreover, they slightly lean towards the cranial part, with the exception of the last vertebra. Its height decreases from the fifth vertebra on. The sacrum has a short, broad, rectangular, dorsoventrally flattened body, consisting of two fused vertebrae (Fig.1).

The caudal vertebrae are fully developed in the cranial region. The transverse processes are well visible only until the fifth caudal vertebra.

The ribs are formed by a long axis, a moderately developed tubercle, which is linked to the processes of the thoracic vertebrae, and a well-developed head, which articulates with the bodies of the vertebrae. They are strongly curved, narrow and thick. There are a total of nine pairs of ribs, which present costal cartilages articulated to the sternum and that are also called real ones. The next two pairs are classified as false ones because they are not directly articu-

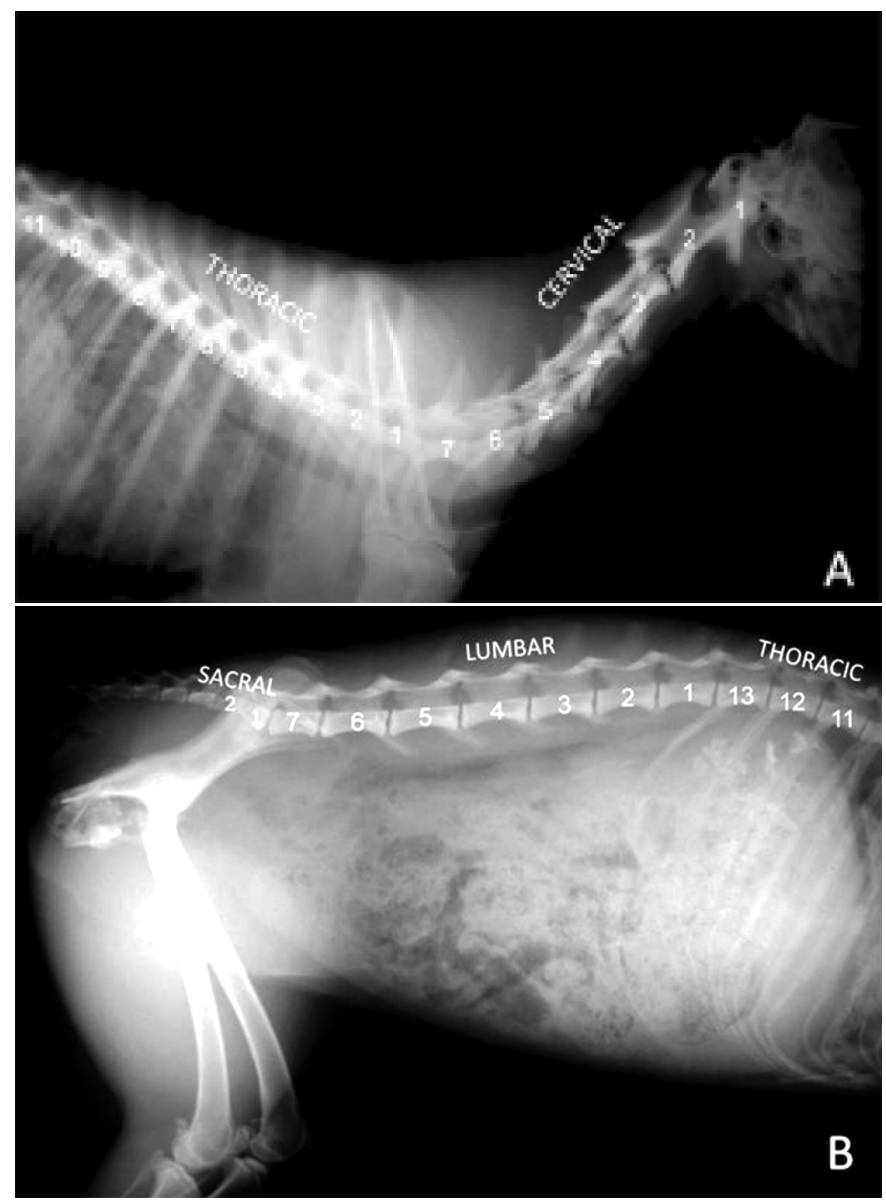

Fig.1. Lateral radiographic image of vertebral column of a crab-eating fox. (A) Cervical (1 to 7) and thoracic vertebrae (1 a 11). (B) Tthe last three thoracic, the seven lumbar and the two sacral vertebrae.

lated to the sternebra. The last two pairs do not articulate, neither directly nor indirectly, to the sternum, and due to that fact they are called floating ones.

The sternum is long, has eight sternebras, as well as manubrium and xiphoid cartilages. The latter is attached to the xiphoid process (eighth sternebra).

\section{DISCUSSION}

The skull of the crab-eating fox has elongated format, as well as incomplete orbits (Constantinescu 2002), similar to domestic dolichocephalic dog (König \& Liebich 2002). The species researched has a greater width at the zygomatic process of temporal bone (Dyce et al. 2010).

Similarly to the domestic dog, the grab-eating fox has seven cervical, thirteen thoracic, and seven lumbar vertebrae (König \& Liebich 2002, Dyce et al. 2010). The bodies of the cervical vertebra decrease gradually towards the cranial-caudal regionand they are dorsoventrally compressed (Sisson 1986). The first cervical vertebra, that is, the atlas, has wide lateral wings, which are also flat, well-developed and with the alar notch present in the cranial border (König \& Liebich 2002; Dyce et al., 2010). The axis has well-developed odontoid and spinous processes and a slightly wider transversal process in-between the distances of the 
two joint caudal surfaces (Dyce et al. 2010). The spinous process of third cervical vertebra is shaped like a long, low ridge; for the rest of it, this process is taller, it has a blunt end and it also is cranially tilted (Sisson 1986). Moreover, the latter process is evident from the fifth vertebra on for the grab-eating fox only.

Also similarly to the domestic dog, the vertebral bodies of the thoracic vertebrae of the crab-eating fox are even larger the more caudal they are (Sisson 1986, König \& Liebich 2002, Dyce et al. 2010). The first three spinous processes are almost perpendicular and have the same length, becoming gradually more oblique and less developed until the tenth vertebra, remaining the same for the last three vertebrae (Sisson 1986, König \& Liebich 2002).

Like the domestic dog, the vertebral bodies of the lumbar vertebrae belonging to the crab-eating fox present well-developed transverse processes, which are cranially and ventrally directed (Dyce et al. 2010). The spinous processes are wide on their ventral portion and narrower on their dorsal portion, they slightly lean cranially, with the exception of the last vertebra (Sisson 1986, Constantinescu 2002). In the grab-eating fox, the height of the spinous process decreases from the fifth vertebra on, unlike the domestic dog, in which this dropping starts from the fourth lumbar vertebra on (Sisson 1986).

The sacrum has a short, broad, rectangular, dorsoventrally flattened body, as also described in the domestic dog (König \& Liebich 2002), consisting of two fused vertebrae though, unlike domestic carnivores which have three fused vertebrae (Sisson 1986, Dyce et al. 2010).

There are a total of nine pairs of ribs, which present costal cartilages articulated to the sternum and that are also called real ones. The next pairs are classified as false ones because they are not directly articulated to the sternebra. The last two pairs of ribs do not articulate, neither directly nor indirectly, to the sternum, and due to that fact they are called floating ones, just like the domestic dog description (König \& Liebich 2002).
The sternum is long, it also has eight sternebras, as well as manubrium and xiphoid cartilage The latter is attached to the xiphoid process (eighth sternebra), just as it is found in the domestic dog (Sisson 1986, König \& Liebich 2002).

\section{CONCLUSION}

We can conclude that the axial skeleton of grab-eating foxes resembles that of the domestic dog. It differs only in the evidence location of some spinous processes of the cervical and the lumbar vertebrae, and in a smaller number of sacral fused vertebrae as well.

\section{REFERENCES}

Constantinescu G.M. 2005. Anatomia Clínica de Pequenos Animais. Guanabara Koogan, Rio de Janeiro. 355p.

Dyce K.M., Sack W.O. \& Wensing C.J.G. 2010. Tratado de Anatomia Veterinária. Elsevier, Rio de Janeiro. 834p.

König H.E. \& Liebich H.-G. 2002. Anatomia dos Animais Domésticos: aparelho locomotor. Artmed, Porto Alegre. 291p.

Oliveira F.S., Canola J.C., Machado M.R.F. \& Camargo M.H.B. 2007a. Descrição anátomo-radiográfica do esqueleto apendicular da paca (Agouti paca Linnaeus, 1766). Acta Sci. Vet. 35:83-87.

Oliveira F.S., Canola J.C., Machado M.R.F. \& Camargo M.H.B. 2007b. Descrição anátomo-radiográfica do esqueleto axial da paca (Agouti paca Linnaeus, 1766). Acta Sci. Vet. 34:331-334.

Oliveira F.S., Martins L.L., Pauloni A.P., Machado M.R.F., Toniollo G.H. \& Canola J.C. 2009a. Descrição anátomo-radiográfica do esqueleto axial da cutia (Dasyprocta azarae Lichtenstein, 1823). Ars Vet. 25:20-23.

Oliveira F.S., Martins L.L., Pauloni A.P., Toniollo G.H., Canola J.C. \& Machado M.R.F. 2009b. Descrição anátomo-radiográfica do esqueleto apendicular da cutia (Dasyprocta azarae Lichtenstein, 1823). Ars Vet. 25:24-27.

Rocha V.J., Reis N.R. \& Sekiama M.L. 2004. Dieta e dispersão de sementes por Cerdocyon thous (Linnaeus) (Carnivorae, Canidae), em um fragmento florestal no Paraná, Brasil. Revta Bras. Zool. 21:871-876.

Rodrigues H. 1998. Técnicas Anatômicas. Arte Visual, Vitória. 222p.

Schaller 0. 1999. Nomenclatura Anatômica Veterinária Ilustrada. Manole, São Paulo. 614p.

Sisson S. 1986. Osteologia, p.1337-1412. In: Getty R. (Ed.), Anatomia dos Animais Domésticos. Guanabara Koogan, Rio de Janeiro. 